\title{
Effect of the Concentration of Depleted Uranium in Soil on Its Uptake by Tomato Plant
}

\author{
Ibrahim B. Razaq ${ }^{1}$, Suad. A. Alsaedi ${ }^{1} \&$ Hamed Sh. Mugheir ${ }^{1}$ \\ ${ }^{1}$ Agricultural Research Directorate, Ministry of Science and Technology, Baghdad, Iraq \\ Correspondence: Ibrahim B. Razaq, Agricultural Research Directorate, Ministry of Science and Technology, \\ Baghdad, Iraq. E-mail: suad_alsadi@yahoo.com
}

Received: January 5, 2019

Accepted: February 13, 2019 Online Published: April 15, 2019

doi:10.5539/jas.v11n5p552

URL: https://doi.org/10.5539/jas.v11n5p552

\begin{abstract}
Depleted Uranium (dU) is usually used in the weapon to increase its destruction power inflected to the target. Therefore, this study was conducted to detrmine the effect of of a range of dU concentration in the soil an incident of the desrruction of military tank in southern part of Iraq on radioisotope content in soil and in tomato plant grown in the area. The dU concentration in the incident spots located in Safwan destrict close to Jabel Sanam, north of Rumala oil field was $4000 \mathrm{mg} \mathrm{Kg}^{-1}$ in the soil. The soil also was found to contain a considerable level of ${ }^{234} \mathrm{Th},{ }^{226} \mathrm{Ra}$ and ${ }^{40} \mathrm{~K}$. Tomato growth was reduced with the increase of dU concentration compared to those grown in same soil of no dU content. It even has failed to grow in the soil with high level of dU. Tomato plant uptake of ${ }^{238} \mathrm{U}$ as determined by radioactivity of its direct daughter ${ }^{234} \mathrm{Th}$ was found to increase with the increase of $\mathrm{dU}$ concentration in soil. The dU concentration higher than $500 \mathrm{mg} \mathrm{kg}^{-1}$ soil was lethal to tomato plant.
\end{abstract}

Keywords: radioisotope, firing site, phosphate fertilizer, organic materials, sandy loam soil

\section{Introduction}

Hundreds of tons of depleted Uranium (dU) were discharged in the environment via ammunition during the wars in Iraq in 1990, 2003 and in Kosovo in 1998. Therefore, international attention has to be paid to the potential danger of $\mathrm{dU}$ to man and environment to all action sites in these two countries. It is well known that serious danger may occur by inhalation and wounds which are the main pathways of direct body contamination.

Uranium is not found free in its elemental state but combined with other elements in about 150 known minerals (McDiarmid \& Squibb, 2001). Uranium exists in nature in the from of three radioactive isotopes including ${ }^{238} \mathrm{U}$ the most abundant $(99.2745 \%),{ }^{235} \mathrm{U}(0.7200 \%)$, and ${ }^{234} \mathrm{U}(0.0055 \%)$ (Lide, 1999).

The ratio of ${ }^{238} \mathrm{U}$ to ${ }^{235} \mathrm{U}$ in natural uranium is 137.88 , and 314.95 in depleted uranium (Roth et al., 2003). Therefore, depleted uranium is so named because it has been partially depleted of radioisotopes, which means the abundance of both ${ }^{235} \mathrm{U}$ and ${ }^{234} \mathrm{U}$ is lower than natural uranium. The chemical properties of depleted uranium are the same as those of the enriched and natural forms (ATSDR, 1999). The specific activity of each isotope is expressed in the International System Units, as $\mathrm{Bq} \mathrm{g}^{-1}$ or $\mathrm{MBq} \mathrm{kg}^{-1}$, where $1 \mathrm{~Bq}$ (becquerel) $=1 \mathrm{dps}$ (decay per second) (Anon XI, 2000; Luckey, 1991).

The soil is usually retaining radionuclides against forces of gravity and leaching as a result of the fact that the soil is charged with a negative electric charge as well as an "important" part of it with a surface size that has wide surface areas, so that the nuclides adhere (adsorbed) to the surface of the colloids according to the "physisorption" or "chemisorption" (Mistry et al., 1973).

In acid soils of tropical environments, $\mathrm{U}$ is retained in soils, through its interaction with iron minerals (Evans et al., 1997; Yoshida et al., 1998). U is mainly accumulated in upper soil layer (A horizons of soils). High organic matter soils are usually of high $U$ contents coming from the sequestration and reduction of $U$ (Fellows et al., 1998; Tipping, 1996).

Average concentrations of $\mathrm{U}$ in phosphate fertilizers are 100 times higher than that of soils phosphate which is a possible source of U in soils (Karhunen \& Vermeulen, 2000; Schnug et al., 1996). 
Uranium uptake by plants from the soil and its translocation within the plant was found to vary depending on plant species (Gulati et al., 1980; Lakshmanan \& Venkateswarlu, 1988; Schnug et al., 1996; Whicker et al., 1999). Very few is known about the responsible mechanisms. It has been proposed that the $U$ distribution in plants followed a pattern similar to $\mathrm{Ca}$, which is accumulated more in older than in younger leaves (Mortvedt 1994). A typical value for $U$ in plant $0.04 \mathrm{mg} \mathrm{kg}^{-1}$, with a maximum of $0.4 \mathrm{mg} \mathrm{kg}^{-1}$ is reported by Vidal Perez et al. (1998) or $0.01 \mathrm{mg} \mathrm{kg}$ reported by Pais and Jones (1997).

$\mathrm{U}$ uptake by plants increases with the increase of $\mathrm{U}$ in the soil or irrigation water (Lakshmanan \& Venkateswarlu, 1988; Singh, 1997). Some species have developed the ability to tolerate high concentration of heavy metals like uranium. Many members of the Brassica species are classified as hyper-accumulators, and hydroponically grown sunflowers (Helianthus annuus) have been reported as a means to remove $\mathrm{U}$ from contaminated waters (Chaney et al., 1997; Salt et al., 1995).

Meyer et al. (1998) found in a substrate contaminated with dU that respiration, the most sensible parameter, was affected at $500 \mathrm{mg} \mathrm{dU} \mathrm{kg}^{-1}$ soil. Meyer and McLendon (1997) found a decrease in plant biomass, and long term survivability at the highest level $\left(25,000 \mathrm{mg} \mathrm{dU} \mathrm{kg}^{-1}\right)$.

It remains necessary to know the quantities of $\mathrm{dU}$ released and quantities absorbed by the plant as well as the best method or the optimal methods of managing soils contaminated with radionuclides. The objective of this work, however, is to evaluate uptake of depleted uranium by tomato plant, the most common crop in the soil of site of action affected by existing and variable concentration.

\section{Materials and Methods}

The experiment was conducted to evaluate the effect of the concentration of depleted uranium (dU) on its uptake by tomato and on tomato growth as well. The experiment was carried out in pots as a closed system to ensure no leakage of substances and radionuclides. Soil was obtained from uranium-contaminated area in Basrah governorate close to Safwan city where intensive military activity was conducted and large number of destroyed tanks existed. Initially, uranium concentration and readioactivity was determined. Soil from a location with no military incident (without any dU content) was also obtained.

The dU-contaminated soil was mixed in a certain ratio with no dU soil of the same area to obtain soil samples with the following selected range of dU concentration: 0, 250, 500, 1000, $4000 \mathrm{ppm}\left(\mu \mathrm{g} \mathrm{g}^{-1}\right)$.

Sufficient amounts of soil of each concentration were prepared. Two kilograms of soil were transferred into each pot and planted with tomato plants (cultivar Super Mermond) with three replicates of each concentration. Pots were irrigated with a nutrient solution (Hoagland and Arnon (1950)'s nutrient solution) containing all plant essential elements.

Plants were harvested at full fruit stage i.e., 90 days after planting. The plants and fruits were harvested individually and dried in oven at $65^{\circ} \mathrm{C}$ for 24 hours. The level of radioactivity was determined in dry matter of the fruits and plant tissues. The radioactivity of the soil, fruits, and plant tissues was measured by Gamma-ray spectrum meters using HPGe detector with efficiency of $30 \%$ (Canberra Company USA). ${ }^{238} \mathrm{U}$ radioactivity was determined using its direct daughter ${ }^{234} \mathrm{Th}$ as suggested by Saleh and Abdil-Halim (2015).

\section{Results}

The properties of the soil of uranium polluted area were given in Table 1. These analyzes showed that the soil is a light-textured soil (sandy loam) with $60 \%$ of its content is sand. Consequently, this type of soil is poor in plant essential elements content. They also had very low water holding capacity and low nutrients retention capacity. This site is mainly used for tomato production using traditional technologies developed by local farmers. That is by mixing an amount of well decomposed organic material with sandy loam to raise organic matter content to $20 \%$ of total weight of soil. Plant seedlings were grown after the appropriate nutrients were given either as mineral fertilizers mixed with organic material or given with irrigation water in the form of water soluble fertilizers and in batches throughout the plant growth and production season. 
Table 1. Chemical and physical properties of soil used

\begin{tabular}{ll}
\hline Properties & Value \\
\hline Clay $\left(\mathrm{gm} \mathrm{kg}^{-1}\right)$ & 171.3 \\
Silt $\left(\mathrm{gm} \mathrm{kg}^{-1}\right)$ & 210.7 \\
Sand $\left(\mathrm{gm} \mathrm{kg}^{-1}\right)$ & 618.0 \\
Soil texture & Sandy loam \\
$\mathrm{EC}\left(\mathrm{dSm}^{-1}\right)$ & 3.5 \\
$\mathrm{pH}$ & 4.7 \\
$\mathrm{Solubility} \mathrm{Ions}\left(\mathrm{mmol} \mathrm{L}^{-1}\right)$ & \\
$\quad \mathrm{Ca}$ & 9.97 \\
$\quad \mathrm{Mg}$ & 5.19 \\
$\quad \mathrm{~K}$ & 0.73 \\
$\quad \mathrm{Na}$ & 3.09 \\
$\quad \mathrm{Cl}$ & 20.01 \\
$\quad \mathrm{SO}$ & 6.01 \\
$\quad \mathrm{HCO}$ & 2.39 \\
Organic mater $\left(\mathrm{g} \mathrm{Kg}^{-1}\right)$ & 3.5 \\
Total N $\left(\mathrm{g} \mathrm{Kg}^{-1}\right)$ & 0.21 \\
$\mathrm{dU}\left(\mathrm{mg} \mathrm{kg}^{-1}\right)$ & 4000 \\
\hline
\end{tabular}

Depleted uranium concentration at firing sites was $4000 \mathrm{mg} \mathrm{kg}^{-1}$ as an average of numerous soil samples analysed (Table 1). Hoagland and Arnon solution was used as a nutrient solution to supply essential elements to tomato plants sufficiently because of extremly low content of plant essential elements of the soil. Tomato was used as an index plant because it is the most common crop in the area. The results of the distribution of uranium isotopes in soil, plant tissues, and fruit were given in Tables 2, 3, 4 and 5, of the soil where the concentrations of depleted uranium were $0,250,500 \mathrm{mg} \mathrm{Kg}^{-1}$, respectively.

The results (Table 3) showed that there are no detectable level of ${ }^{234} \mathrm{Th},{ }^{226} \mathrm{Ra}$, and ${ }^{40} \mathrm{~K}$ in the sites where no incident occurred (control soil). Therefore, radioactivity in plant grown in control soil was as low as $13.0 \mathrm{~Bq}$ $\mathrm{Kg}^{-1}$ for both Radon and Lead while potassium- 40 content in plant was 5 times higher than radon content and 10 times higher than that lead. Three times the activity of potassium ${ }^{40} \mathrm{~K}$.

Table 2. Radioactive isotopes in soil of $4000 \mathrm{mg} \mathrm{Kg}^{-1} \mathrm{dU}$

\begin{tabular}{ll}
\hline Isotope & Soil $\left(\mathrm{Bq} \mathrm{Kg}^{-1}\right)$ \\
\hline${ }^{234} \mathrm{Th}$ & $51741 \pm 280$ \\
${ }^{226} \mathrm{Ra}$ & $48327 \pm 98$ \\
${ }^{235} \mathrm{U}$ & $833 \pm 51$ \\
${ }^{214} \mathrm{~Pb}$ & $3122 \pm 45$ \\
${ }^{214} \mathrm{Bi}$ & $2878 \pm 61$ \\
${ }^{234} \mathrm{~Pa}$ & $55735 \pm 921$ \\
${ }^{40} \mathrm{~K}$ & $2281 \pm 60$ \\
${ }^{234} \mathrm{Th} /{ }^{235} \mathrm{U}$ & 62.114 \\
\hline
\end{tabular}


Table 3. Radioactivity of control soil, plant and tomato fruits

\begin{tabular}{llll}
\hline Isotope & Control Soil & Plant tissues & Fruits \\
\hline${ }^{234} \mathrm{Th}$ & $---------------------\mathrm{Bq} \mathrm{Kg}^{-1}-----------------------$ \\
${ }^{226} \mathrm{Ra}$ & $67.2 \pm 6$ & - & - \\
${ }^{235} \mathrm{U}$ & $58.4 \pm 13$ & $12.2 \pm 1.4$ & $5.3 \pm 1.1$ \\
${ }^{214} \mathrm{~Pb}$ & - & - & - \\
${ }^{214} \mathrm{Bi}$ & $16.5 \pm 1.1$ & $6.7 \pm 3.5$ & $1.3 \pm 0.5$ \\
${ }^{234} \mathrm{~Pa}-\mathrm{m}$ & $13.7 \pm 2.2$ & $4.5 \pm 1.5$ & $1.6 \pm 0.7$ \\
${ }^{40} \mathrm{~K}$ & - & - & - \\
\hline
\end{tabular}

In the soil containing $250 \mathrm{mg} \mathrm{kg}^{-1}$ of dU (Table 4), radioactive isotopes were detected in the soil where ${ }^{234} \mathrm{Th}$ and ${ }^{234} \mathrm{~Pa}$ were the highest, in absolute terms. In the plant tissues (dry matter), the ${ }^{234} \mathrm{Th}$ was the highest while there was no radiation activity in the fruit.

Table 4. Radioactivity of soil and tomato plant for $250 \mathrm{mg} \cdot \mathrm{Kg}^{-1}$ concentration

\begin{tabular}{llc}
\hline Isotope & Soil & \multicolumn{1}{c}{ Plant tissue } \\
\hline${ }^{234} \mathrm{Th}$ & $----------------\mathrm{Bq} \mathrm{Kg}^{-1}-----------------$ \\
${ }^{226} \mathrm{Ra}$ & $3167.27 \pm 75$ & $43.6 \pm 8$ \\
${ }^{235} \mathrm{U}$ & $2941.23 \pm 64$ & $5.3 \pm 1.3$ \\
${ }^{214} \mathrm{~Pb}$ & $233.2 \pm 71$ & - \\
${ }^{214} \mathrm{Bi}$ & $49.3 \pm 12$ & $8.9 \pm 0.7$ \\
${ }^{234} \mathrm{~Pa}-\mathrm{m}$ & $36.2 \pm 1$ & $6.5 \pm 0.4$ \\
${ }^{40} \mathrm{~K}$ & $3310 \pm 45$ & - \\
${ }^{234} \mathrm{~Pa}-\mathrm{m}$ & $160.3 \pm 22$ & $70.6 \pm 8$ \\
${ }^{234} \mathrm{Th}$ & 0.956 & \\
${ }^{234} \mathrm{Th} /{ }^{235} \mathrm{U}$ & 13.581 & \\
\hline
\end{tabular}

The concentration ratio (CR), which was defined as concentration of total $\mathrm{U}$ in plant tissue/concentration of total $\mathrm{U}$ in the soil, determined the probability of the transfer of uranium from the soil to human diet.

In the soil containing $500 \mathrm{mg} \mathrm{kg}^{-1}$ of $\mathrm{dU}$ (Table 5), the radiation activity of all uranium isotopes increased. ${ }^{234} \mathrm{~Pa}$ and ${ }^{234} \mathrm{Th}$ were the highest and no radiation activity was observed in the fruits. ${ }^{234} \mathrm{Th},{ }^{214} \mathrm{~Pb}$ and ${ }^{214} \mathrm{Bi}$ were found in plant tissues.

Table 5. Radioactivity of soil and Tomatoe plant for $500 \mathrm{mg} \cdot \mathrm{Kg}^{-1}$ concentration

\begin{tabular}{|c|c|c|c|}
\hline Isotope & Soil & Plant tissues & Fruits \\
\hline & ------- & $\mathrm{Bq} \mathrm{Kg}^{-1}$ & \\
\hline${ }^{234} \mathrm{Th}$ & $6270 \pm 7.7$ & $50.3 \pm 7.6$ & - \\
\hline${ }^{226} \mathrm{Ra}$ & $5975 \pm 45$ & $7.6 \pm 0.8$ & - \\
\hline${ }^{235} \mathrm{U}$ & $270 \pm 22$ & - & - \\
\hline${ }^{214} \mathrm{~Pb}$ & $66.7 \pm 17$ & $17.3 \pm 3.6$ & - \\
\hline${ }^{214} \mathrm{Bi}$ & $50.5 \pm 19$ & $12.6 \pm 2.1$ & - \\
\hline${ }^{234} \mathrm{~Pa}-\mathrm{m}$ & $6520 \pm 86$ & -- & - \\
\hline${ }^{40} \mathrm{~K}$ & $240 \pm 33$ & $75 \pm 13$ & - \\
\hline${ }^{234} \mathrm{~Pa}-\mathrm{m}$ & & & \\
\hline${ }^{234} \mathrm{Th}$ & 0.956 & & \\
\hline${ }^{234} \mathrm{Th} /{ }^{235} \mathrm{U}$ & 23.222 & & \\
\hline
\end{tabular}


Plant content of uranium and related radioisotopes in soil containg $500 \mathrm{mg} \mathrm{kg}^{-1}$ of dU (Table 5) was markedly reduced compared to those of tomato grown in same soil containing $250 \mathrm{mg} \mathrm{kg} \mathrm{of} \mathrm{dU}^{-1}$. Concentrations of $1000-4000 \mathrm{mg} \mathrm{kg}^{-1}$ of uranium in the soil has led to the death of the plant and its inability to complete its life cycle.

\section{Discussion}

Uranium was widely distributed in soil crust where its concentration was estimated to be about $32.9 \mathrm{~Bq} \mathrm{Kg}^{-1}$ and varied depending on soil type and the quality of its constituent rocks. However, uranium concentration in the soils at which incidents of tank bombardment was as high as 10,000 ppm dU and the least concentration obtained in our laboratories was $4000 \mathrm{ppm}$. This value is two and half time less than reported by Mason et al. who had reported that du in soil could exceed $10,000 \mathrm{mg} \mathrm{du} \mathrm{kg}^{-1}$ during the investigation of many different sources of $\mathrm{U}$ identified at this place.

Tomato plant was selected as the "Index Plant" because it is the common crop cultivated in the region. In the sites of no bombardment activity radioisotopes content was exactly as those in natural soils which clearly indicate that there is no cross contamination in the area between incident and nonincident sites.

In all cases dU content in plant increased with higher values of $U$ in soils or water which was in agreement with results reported by Lakshmanan and Venkateswarlu (1988), and Singh (1997).

The CR of dU in tomato plant grown in soil containing $250 \mathrm{mg} \mathrm{Kg}^{-1}$ of dU was 0.004 which is close to the value reported by Mortvedt (1994), and Sheppard and Evenden (1988) who found that geometric means of CR for U was 0.0045 depending on soil properties and crop species.

Uranium concentration as high as 500 ppm severly reduced plant growth in contrast with what had been reported by Meyer et al. (1998) and Meyer and McLendon (1997), who found decrease in plant biomass, and long term survivability occurred at at the highest level $\left(25,000 \mathrm{mg} \mathrm{kg}^{-1}\right.$ of dU).

\section{Conclusions}

The dU concentration in tanks and vechiles destruction area close to Safwan bordered city as an average over large number of soil sample was $4000 \mathrm{mg} \mathrm{kg}^{-1}$ of soil. Plant uptake of depleted uranium affects the growth of the tomato negatively. dU concentration as high as $500 \mathrm{ppm}$ severly reduced rowth of tomato plant in sandy soil of Safwan area at southern part of Iraq.

\section{References}

ATSDR (Agency for Toxic Substances and Disease Registry). (1999). Toxicological profile for uranium (An update). ATSDR, Atlanta, USA.

Anon, X. I. (2000). Uranium radiation properties. Retrieved from http://www.antenna.nl/wise/uranium/rup.html

Chaney, R. L., Malik, M., Yin, M. L., Brown, S., Brewer, E. P., Angle, J. S., \& Baker, A. J. M. (1997). Phytoremediation of soil metals. Current Opinion in Biotechnology, 8, 279-284. https://doi.org/10.1016/ S0958-1669(97)80004-3

Evans, C. V., Morton, L. S., \& Harbottle, G. (1997). Pedologic assessment of radionuclide distributions: Use of a radio-pedogenic index. Soil Sci. Soc. Am. J., 61, 1440-1449. https://doi.org/10.2136/sssaj1997.03615995006 $100050023 \mathrm{x}$

Fellows, R. J., Ainsworth, C. C., Driver, C. J., \& Cataldo, D. A. (1998). Dynamics and transformations of radionuclides in soils and ecosystem health. Soil Chemistry and Ecosystem Health. Soil Science Society of America, 52, 85-112.

Fukai, R., \& Murray, C. N. (1973). Environmental behavior of radiocobait and Radiosilver released from nuclear power stations into aquatic system (pp. 217-242).

Gulati, K. L., Oswal, M. C., \& Nagpaul, K. K. (1980). Assimilation of uranium by wheat and tomato plants. Plant and Soil, 55, 55-59. https://doi.org/10.1007/BF02149708

Hoagland, D. R., \& Arnon, D. I. (1950). The water culture method for growing plants without soil. California Agric. Exp. Station Cric, 347, 1-32.

Karhunen, J., \& Vermeulen, S. (2000). Natural radioactivity of phosphates and phosphogypsum. Fertilizer International, 378, 75-81. 
Kuhn, W., Handle, J., \& Schatzler, H. P. (1973). Transport of ${ }^{131} \mathrm{I},{ }^{137} \mathrm{Cs},{ }^{106} \mathrm{Ra},{ }^{144} \mathrm{Ce}$ and ${ }^{54} \mathrm{Mn}$ in undisturbed soil under natural environmental conditions. Environmental Behavior of Ralionuchides Released in Nuclear Industry IAEA No. STL/PUB/345, 347-361.

Lakshmanan, A. R., \& Venkateswarlu, K. S. (1988). Uptake of uranium by vegetables and rice. Water, Air and Soil Pollution, 38, 151-155.

Lide, D. R. (1999). CRC handbook of chemistry and physics (80th ed.). Boca Raton, FL: CRC Press.

Luckey, T. D. (1991). Radiation hormesis (p. 306). CRC Press, Inc.

Mason, C. F. V., Turney, W. R. J. R., Thomson, B. M., Lu, N., Longmire, P. A., \& Chisholm-Brause, C. J. (1997). Carbonate leaching of uranium from contaminated soils. Environmental Science \& Technology, 31, 2707-2711. https://doi.org/10.1021/es960843j

McDiarmid, M. A., \& Squibb, K. S. (2001). Uranium and thorium. In E. Bingham, B. Cohrssen, \& C. H. Powell (Eds.), Patty's toxicology (5th ed., pp. 381-421). New York, John Wiley and Sons Inc. https://doi.org/ 10.1002/0471435139.tox042

Meyer, M. C., \& McLendon, T. (1997). Phytotoxicity of depleted uranium on three grasses characteristic of different successional stages. Journal of Environmental Quality, 26(3), 748-752. https://doi.org/10.2134/ jeq1997.00472425002600030022x

Meyer, M. C., McLendon, T., \& Price, D. (1998). Evidence of depleted uranium-induced hormesis and differential plant response in three grasses. Journal of Plant Nutrition, 21(11), 2475-2484. https://doi.org/ $10.1080 / 01904169809365579$

Mistry, K. B., Bhujbal, B. M., \& D’Souza, T. J. (1973). Influence of agronomic practice on uptake of fission products by crops from soils of regions adjoining nuclear installations in India (pp. 303-318).

Pais, I., \& Benton, J. Jr. J. (Eds.). (1997). The Handbook of trace elements. St. Lucie CRC Press.

Roth, P., Hollriegl, V., Werner, E., \& Schramel, P. (2003). Assessment of exposure to depleted uranium. Radiation Protection Dosimetry, 105(1-4), 157-161. https://doi.org/10.1093/oxfordjournals.rpd.a006213

Saleh, I. H., \& Abdul-Halim, A. A. (2016). Determination of depleted uranium using a high-resolution gamma-ray spectrometer and its application in soil and sediments. J. Taibah University for Science, 10(2), 205-211. https://doi.org/10.1016/j.jtusci.2015.02.015

Salt, D. E., Blaylock, M., Nanda, K. P. B. A., Dushenkov, V., Ensley, B. D., Chet, I., \& Raskin, I. (1995). Phytoremediation: A novel strategy for the removal of toxic metals from the environment using plants. Biotechnology, 13, 468-474.

Saric, M. R, Stojanovic, M., \& Babic, M. (1995). Uranium in plant species grown on natural barren soil. Journal of Plant Nutrition, 18(7). https://doi.org/10.1080/01904169509364999

Schnug, E., Haneklaus, S., Schnier, C., \& Scholten, L. C. (1996). Issues of natural radioactivity in phosphates. Communications in Soil Science \& Plant Analysis, 27(3\&4), 829-841. https://doi.org/10.1080/0010362960 9369600

Sheppard, M. I., Sheppard, S. C., \& Thibault, D. H. (1984). Uptake by plants and migration of uranium and chromium in field lysimeters. Journal of Environmental Quality, 13(3), 357-361. https://doi.org/10.2134/ jeq1984.00472425001300030007x

Singh, K. P. (1997). Uranium uptake by plants. Current Science, 73(6), 532-535.

Tipping, E. (1996). Hydrogeochemical modelling of the retention and transport of metallic radionuclides in the soils of an upland catchment. Environmental Pollution, 94(2), 105-116. https://doi.org/10.1016/S0269-7491 (96)00086-3

Vidal Perez, D., Da Costa Saldanha, M. F., Costa, M. J., \& Vaitsman, D. S. (1998). Concentracao Total de U e Th em alguns solos brasileiros. Pesq. Agropec. Bras. Brasilia, 33(8), 1417-1423.

Whicker, F. W., Hinton, T. G., Orlandini, K. A., \& Clark, S. B. (1999). Uptake of natural and anthropogenic actinides in vegetable crops grown on a contaminated lake bed. Journal of Environmental Radioactivity, 45, 1-12. https://doi.org/10.1016/S0265-931X(98)00076-9

Yoshida, S., Muramatsu, Y., Tagami, K., \& Uchida, S. (1998) Concentration of lanthanide elements, Th and U in 77 Japanese surface soils. Environment International, 24(3), 275-286. https://doi.org/10.1016/S0160-4120 (98)00006-3 
Zajiv, V. (2000). Review of radioactivity, military use, and health effects of depleted uranium. Retrieved from http://vzajiy.tripod.com.html

\section{Copyrights}

Copyright for this article is retained by the author(s), with first publication rights granted to the journal.

This is an open-access article distributed under the terms and conditions of the Creative Commons Attribution license (http://creativecommons.org/licenses/by/4.0/). 